\title{
Product Relationship Confidentiality Code
}

National Cancer Institute

\section{Source}

National Cancer Institute. Product Relationship Confidentiality Code. NCI Thesaurus. Code C95382.

A coded value specifying privacy requirements for information about the product relationship. 